Nataliia Kotenko,

Ph.D., Associate Professor, Sumy State University, Ukraine

(iD) ORCID ID, 0000-0002-6972-7780

email: n.kotenko@finance.sumdu.edu.ua

Viktoriya Bohnhardt,

Entrepreneur, Germany

email: boenhards@gmx.de

Correspondence author: n.kotenko@finance.sumdu.edu.ua

\title{
DIGITAL HEALTH PROJECTS FINANCING: CHALLENGES AND OPPORTUNITIES
}

Abstract. The article summarizes current trends in financial support for digital health in Ukraine, considering the requirements and recommendations of international institutions. The research goal is to identify problems and challenges in public funding in Ukraine and find effective ways to solve them based on world experience. The systematization of scientific sources and approaches to solving the problem of financing digital health projects has shown that most studies present the results on finding effective mechanisms for financing health care or technical aspects of digital health and its components. However, under the WHO report, the lack or insufficient level of sustainable funding is an insuperable obstacle for implementing digital health projects in most countries. Thus, the above confirmed the relevance of the investigated scientific problem. Methodical tools of this research were systematization, structural and comparative analyses, logical generalization. The practical implementation of the study was carried out using the tools of Excel 2016. In the study, the start point for gathering data was 2016, which is the beginning of the digital health transformation in Ukraine. For gaining the research goal, this study was conducted in the following logical sequence: analyzing the effectiveness and stability of budget funding for the electronic health record projects in Ukraine within the eHealth initiative; defining the current state of Telemedicine and Mobile Medicine financings; identifying the potential directions for solving the problem of lack of funding based on world experience; determining the innovative digital medicine projects implemented by startups; setting the relationship between the amount of venture financing, the maturity and number of employees of companies. Following the findings, the authors developed the recommendations to use Al, Big Data, blockchain technologies, the Internet of Things to establish cooperation between the private, public sectors, academia, and non-governmental organizations.

Keywords: artificial intelligence, big data, budget reimbursement, eHealth, electronic health records, funding, mHealth, public policy, public-private partnership, telemedicine.

Introduction. According to the OECD, the proportion of adults seeking online health information has doubled in the last nine years. However, the demand growth on health information did not significantly affect the investment into information and communications technologies of the medical sector (ICT). It stands to mention that the investment volume is the lowest among other economic sectors (OECD, 2020). However, the COVID-19 pandemic has broken down the regulatory, psychological, and financial barriers between digitalization and the healthcare system. In turn, most governments are looking for an effective mechanism for public funds management to provide quality health services. The World Health Organization and the OECD insist that the widespread use of ICTs would improve the health service quality while reducing their cost.

On May 26, 2018, the Seventy-first World Health Assembly stressed the importance of digital health in achieving the Sustainable Development Goals, particularly Goal 17: Strengthen the means of implementation and revitalize the global partnership for sustainable development (WHO, 2018). It was stated that the regulatory assistance, technical guidance, and advice would promote financing and introducing digital health business models.

Cite as: Kotenko, N., \& Bohnhardt, V. (2021). Digital Health Projects Financing: Challenges and Opportunities. Health Economics and Management Review, 1, 100-107. http://doi.org/10.21272/hem.2021.1-10 100 
Deloitte's experts highlighted the fundamental changes in the global health care system caused by the COVID-19 rush spread. Notably, it resulted in public-private collaborations between organizations, industry, academic community, and governments for vaccination and treatment (Allen, 2021). It worth mentioning that these changes require a review of business models and funding for health care systems worldwide.

Literature Review. Systematization of scientific background devoted to investigated issue allowed to notice the growing interest of domestic and foreign authors in exploring digital health and health care financing.

Notably, in the study (Serpeninova et al., 2020), the authors analyzed and mapped the responsible investment instruments in health care under United Nations Development Programme (UNDP) methodology, theoretical approaches, and practical recommendations by USAID, and the parameters of the World Bank.

On the other hand, Samoilikova and Kunev (2020) assessed the impact of health care financing on national economic development. The findings proved its strong positive impact in most investigated countries (64\%), while the negative impact was noticed in the rest of them.

Therefore, it stands to mention the constantly growing interest in ICT implementation in medicine (Figure 1a). According to the GoogleTrends data, the search request «Digital Health» jumped the shark in August 2020. Notably, in most Central and Eastern European countries and some Asian countries, the search queries «e-health» predominated (Figure 1b).

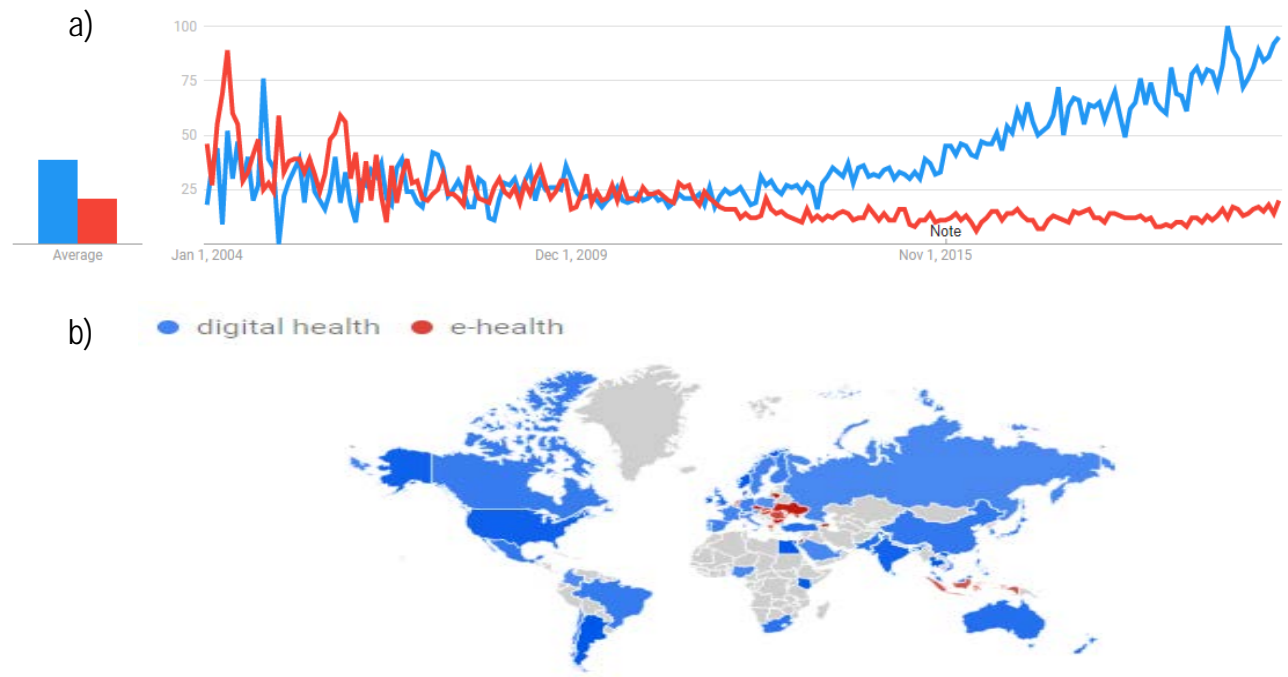

Figure 1. Comparison of the search requests «Digital Health» and «e-health» a) trends; b) by regions

Sources: вумудщзув by the authors using Google Trends online instrument.

The emergence of «e-health» formulation was thanks to marketers who used the analogy of other edomains such as e-commerce, e-government, e-business. It is worth noting that involving the prefix «e-» means combining electronic communications and information technology and better quality health services (André, 2018). 
Zhang et al. (2018) proposed considering digital health as a scientific field, not just as one of the varieties of interdisciplinary practices. In the frame of the study (Unnithan et al., 2019), the authors explored the role of blockchain technology in digital health and electronic medical records.

Despite the high scientific interest in digital health, international organizations such as the World Health Organization (WHO) and the OECD conduct the most in-depth and systematic research on health financing and the global spread of digital health.

Herewith, the WHO defines e-health as using electronic means to obtain information, resources, and services related to health, such as electronic health records, m-health (applications, mobile or body devices); telemedicine (consultations with doctors via PC or mobile devices); medical e-initiation (both for patients and medical staff); social media (including informal, social online communication channels); analysis of medical data and «big data» (to obtain evidence in decision-making or policy-making on health care reform) (WHO, 2018).

Methodology and research methods. This study involves several research methods: systematization, structural and comparative analysis, logical generalization to assess the current state of financing of digital health projects in Ukraine, and its compliance with the expectations of international organizations. For identifying the most attractive venture financing startups in medical equipment development, Excel 2016 tools were used. This study hypothesis is that there are gaps and reserves for development in financing digital health projects in Ukraine.

Results. Electronic health records. Since March 2019, the eHealth system of electronic medical records has been operating in a test mode in Ukraine. Notably, the implementation of this project was carried out supported by international donors.

In Ukraine, the National Health Service of Ukraine (NHSU) ensures the functioning of the eHealth system. In turn, the NHSU reports do not specify the funding, only a general list of partners providing expert and financial assistance. It stands to indicate the main international donors such as the WHO, the World Bank, Swiss Agency for Development and Cooperation, United Nations Children's Fund (UNICEF), United States Agency for International Development (USAID), UK Government (UKAid), Global Fund to Fight AIDS, Tuberculosis, and Malaria, EU Delegation in Ukraine, and the Government of Canada through Canada's Department of Foreign Affairs, Trade and Development, the Renaissance International Charitable Foundation, the US Centers for Disease Control and Prevention, European Embassies in Ukraine, etc. (NHSU, 2020).

The analysis of the financial documents of the National Health Insurance Fund (NHSU, 2021) for the last three years showed that the Passports of the budget program provided KPKVK 2308010 certain expenditures for the functioning of the eHealth system were for 2019 and 2020.

Table 1 demonstrates the work capacity of the budget program is less than half, while the share of expenditures on eHealth is less than $10 \%$.

Table 1. Analysis budget financing for support and servicing eHealth for 2019-2020

\begin{tabular}{cccccc}
\hline Year & Plan & Actual & $\begin{array}{c}\text { Proportion in budget } \\
\text { program }\end{array}$ & Deviation from a plan & \% of implementation \\
\hline 2019 & 18000 & 8049 & 4,2 & -9951 & 44,7 \\
2020 & 33327,3 & 15593,2 & 7,2 & 17734,1 & 46,8 \\
\hline
\end{tabular}

Sources: developed by the authors based on (NHSU, 2020).

Moreover, expenditures in even the approved passport of the budget program changed during the budget period. While at the approval time, they amounted to only $9 \mathrm{mln} \mathrm{UAH}$, in October, it increased to $16.5 \mathrm{mln}$ UAH. In the final version approved on December 7, 2020, the expenditures amounted to 33327.3 ths UAH. Therefore, it highlights the instability of funding for eHealth support and maintenance in Ukraine. 
On the other hand, there are some concerns regarding the stability of the business entity administrating the Central Database of eHealth of Ukraine and is responsible for the digital transformation of the domestic health care system. Established on December 14, 2017, the company generated property from the sources as follows: state property, income from securities, loans from banks and other creditors, capital investments and subsidies from budgets, and other types of income not prohibited by law. An analysis of the company's financial statements posted on the official website (NHSU, 2021) showed that the company's operations were profitable only the first year. In 2019, a net loss of 165.7 ths UAH was declared. In the first half of 2020, its amount increased almost 23 times to 3740.3 ths UAH.

Besides, data on the presence and amount of tax debt confirmed the State Enterprise «Electronic Health» financial instability (Fig. 2).

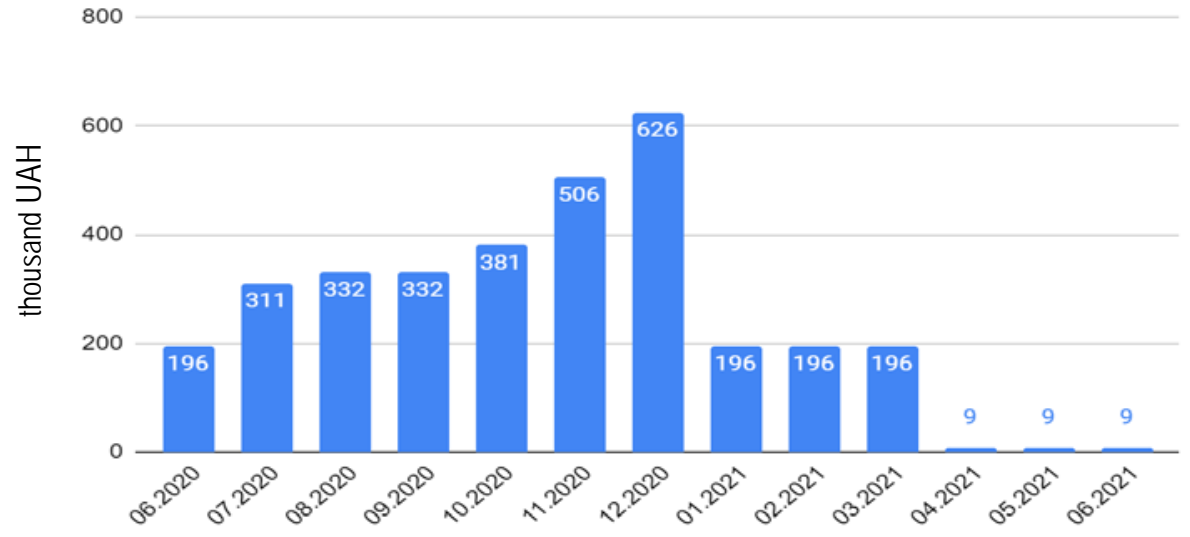

Figure 2. Dynamic of tax debt of the State-Owned Enterprise «Electronic Health»

Sources: developed by the authors based on (State, 2021)

Indeed, the growth of the number of connected patients, physicians, or platforms/applications indicates the development of the eHealth system in Ukraine. However, there are problems with funding for uninterrupted performance, protection, and kernel upgrade or updating the central database. It stands to mention that downturn of the above problems could nullify all advancement on digitalization of health care in Ukraine. Oderkirk (2021) showed that medical data is sensitive. Data loss or misinterpretation could cause personal, social, or financial harm to citizens and devalue trust in the government and its initiatives.

Therefore, it is appropriate to list some existing ways to overcome the problem mentioned above:

- developing and validating the eHealth development concept, while its strict compliance would attract the international donors to continue cooperation and finance support for system development;

- introducing paid access to secondary depersonalized data sets. Oderkirk (2021) systemized the experience of developed countries. The findings showed that the national health care databases of Denmark, Finland, Sweden, and the USA are fully available for data collection. In turn, other countries provide access only to certain components of databases, such as hospital data, ambulances, prescriptions, mortality, etc. Besides, paid access could be shared specifically, for example, for scientists or external analysts. Besides, the paid access could be provided to database services, but not to data, through an internal authorized network, and so on.

Telehealth and mHealth. According to WHO approaches, telemedicine (Telehealth) is the interaction between the healthcare provider and the patient distantly in real-time (synchronously) and save-and-send format (asynchronously) (WHO, 2016). Notably, the most promising and common types of telemedicine 
are as follows: Teleradiology, Teledermatology, Telepathology, Telepsychiatry, and remote follow-up of patients.

MHealth involves mobile technology (mobile phones, devices for patient follow-up, personal digital assistants (PDAs), and wireless devices) to support medical information and medical practice (WHO, 2016).

In Ukraine, the most common concept of telemedicine covers the extent of mobile health. It includes «a set of actions, technologies, and measures used to provide health care, using remote communication by e-mail messaging» (Order, 2015). Despite telemedicine is strictly regulated (informed consent must be signed), there is no need for an additional license. The telemedicine could be provided by health care institutions regardless of the level, form of ownership, sole trader, or private individual engaged in health businesses. Moreover, the legislative organizing of health care under telemedicine does not contain any information on its financing.

In 2016, telemedicine list of paid services provided by government, municipal health care institutions, higher medical and educational institutions was expanded by the laboratory, diagnostic, and consulting services at the request of citizens without a doctor's referral; health care for sick patients at home (diagnostic examination, procedures, manipulations, counseling, care); health care under contracts with business entities, insurance companies (including the Social Insurance Fund of Ukraine) and foreign citizens temporarily staying in Ukraine (including insurance contracts) (Resolution of the Cabinet of Ministers, 2016). Thus, telehealthcare could be financed from any source, including the patient's funds. The data analysis presented by the two most famous Ukraine telemedicine portals Medbrama and Telemed of Medstar Solutions showed the lack of open data on the service fee provided and funding sources.

At the same time, according to the OECD study conducted in 2015, 28 member-countries determined public funds as the main source of funding for telemedicine. Herewith, the Czech Republic, New Zealand, and Switzerland provide public and private funding, while Latvia - donor/non-public funding (Oliveira , 2020).

The WHO investigation showed that the major challenges in telemedicine development were as follows:

- lack of technical skills and experience of staff to implement and support telemedicine;

- critically low level of technology and information literacy, psychological barriers of elderly patients;

- difficulties in assessing the benefits of telemedicine by the method of Cost-Benefit-Analisis since they are long-term (aimed to overcome the effects of chronic diseases or preventive care). In terms of program-targeted budgeting, public funds are usually redistributed not in favor of delayed results;

- small private health care providers are reluctant to invest in telemedicine and create a telemedicine portal to serve only their patients.

Innovative Digital Health Projects. The analysis of the world experience showed that in addition to databases of electronic health records, telemedicine, and mobile medicine, the most relevant digital health projects are electronic medical devices, cloud computing, big data, and artificial intelligence, the Internet of Things. It stands to mention that mostly they were initiated and developed by large multinational medical corporations equipped with a resource base or startups.

In Ukraine, entrepreneurial ideas are financed by equity, banks, financial companies, insurance companies, credit unions, pension funds, and pawnshops. According to the OECD, the agricultural sector in Ukraine receives the most significant financial support. There are no state and international donor programs to support the financing of startup projects in the field of digital health (OECD, 2020),

Another alternative funding source for small and medium-sized businesses is crowdfunding models that «operate based on Internet platforms» (Apalkov, 2018). Among the analyzed models in the Asia- 
Pacific region, charitable crowdfunding is used for «health» financing, while equal business financing - for Biotechnology, Medtech, and E-health.

However, the findings showed that venture financing demonstrates the most impressive indicators of financial support. Analysis of indicators of venture capital funding of startups showed on development of medical devices showed that investors were most active in startups founded in 2013-2015 (Fig. 3). Thus, relatively mature projects with more than six years of experience are more attractive for investors.

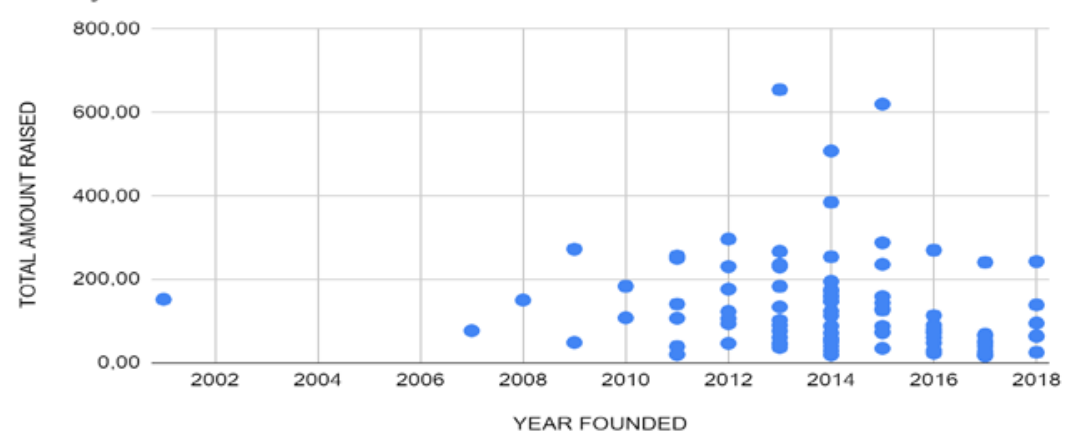

Figure 3. Distribution of medical device startups by total amount raised and years of foundation Sources: developed by the authors.

The obtained results on the raised money by startups regarding the number of employees showed that the market for medical devices has the most significant number of small startups (with 51 to 200 employees). Thus, their financing has a great weight in venture capital (Table 2). However, the situation in the last column shows that the larger the startup, the more money it could raise.

Table 2. Startup funding indicators for developing medical devices by the number of employees

\begin{tabular}{cccc}
\hline Number of employees & Number of startups & Total amount raised & Average amount raised per startup \\
\hline $11-50$ & 22 & 1325,1 & 60 \\
$51-200$ & 53 & 7194,8 & 136 \\
$201-500$ & 14 & 2353,6 & 168 \\
$501-1,000$ & 2 & 365,1 & 183 \\
$1,001-5,000$ & 1 & 266,7 & 267 \\
\hline
\end{tabular}

Sources: developed by the authors based on (Tippmann, 2020).

This funding distribution proves that venture capital is available only from the second development stage of startups despite the flourishing digital medicine market activity (Kasyanenko and Kotenko, 2019). Besides, most entrepreneurs consider public funding (government subsidies and funding) to be critical.

Conclusions. The study findings showed that the modern digital medicine system aims to achieve three key goals: 1) improving medical services, 2) protecting patient data, and 3) reducing costs.

On the other hand, the national and international experience in funding the e-health projects showed that the main challenge is the deficit and sometimes lack of sustainable funding of budget expenditures to ensure the uninterrupted operation, improvement, and development of e-health. Besides, exacerbating the problem is the sensitivity of the data used to external threats, which requires an extraordinary cybersecurity approach with additional funding. 
Using Al, Big Data, blockchain technologies, the Internet of Things could solve the technical problems of digital health. However, these technologies are high-value, while their applications are innovative and sometimes risky. Therefore, it is critical to establish cooperation between the private, public sectors, academia, and non-governmental organizations in limited public funds (particularly topical for developing countries). In turn, the subject of further research should be investigating the question of scientific substantiation of the alignment of interests of these persons.

Author Contributions: conceptualization, N. K. and V. B.; methodology, N. K.; validation, N. K. and V. B.; formal analysis, N. K.; investigation, N. K. and V. B.; writing-original draft preparation, N. K.

Funding: This research received no external funding.

\section{References}

Allen, S. (2021). 2021 Global Health Care Outlook. Accelerating industry change. Deloitte Insights. Retrieved from [Link] André, A. (Ed.). (2018). Digital Medicine. Springer. [CrossRef]

Apalkov, C. (2018). Influence of the world market of alternative finance on the development of small and medium businesses

(SMEs)j. Theoretical and Practical Aspects of Economics and Intellectual Property, 17, 129-135. Retrieved from [Link]

Deloitte. (2020). Digital transformation and interoperable data. Retrieved from [Link]

Elenko, E., Underwood, L., \& Zohar, D. (2015). Defining Digital Medicine. Nature biotechnology, 33(5), 456-461. [Google Scholar] [CrossRef]

Hashiguchi, T. C. O. (2020). Bringing health care to the patient: An overview of the use of telemedicine in OECD countries. OECD Health Working Papers. [Google Scholar] [CrossRef]

Kasianenko, V., \& Kotenko, N. (2019). The issue sustainability startup financing during the life cycle. Visnyk of Sumy State University. Economy series, 3, 117-123. [CrossRef]

NHSU. (2020). National health service report of Ukraine. Retrieved from [Link]

NHSU. (2021). Financial documents. Retrieved from [Link]

Oderkirk, J. (2021). Survey results: National health data infrastructure and governance. [Google Scholar] htt[CrossRef]

OECD. (2017). Digital health. OECD official site. Retrieved from [Link]

OECD. (2020). Ukraine in Financing Financing SMEs and Entrepreneurs 2020: An OECD Scoreboard, OECD Publishing, Paris CrossRef

Official website Ezdorovya._Retrieved from [Link]

Order of the Ministry of Health of Ukraine № 681 of October 19, 2015 (2015). The procedure for organizing health care at the primary, secondary (specialized), tertiary (highly specialized) levels with telemedicine. Retrieved from [Link]

Resolution of the Cabinet of Ministers № 648 of September 22, 2016 (2016). On the statement of the list of paid services provided in the state and municipal health care institutions and higher medical educational institutions. Retrieved from [Link] Samoilikova, A., \& Kunev, R. (2020). The impact of health care financing on the economic growth: EU countries analysis. Health Economics and Management Review, 1(2), 24-32. [Google Scholar] [CrossRef]

Serpeninova, Yu., Makarenko, I., Plastun, A., Babko, A., \& Gasimova, G. (2020). Mapping of the Responsible Investments Instruments in SDG 3 «Good Health and Well-Being» Financing: EU and US experience. Health Economics and Management Review, 1, 106-115. [Google Scholar] [CrossRef]

State Tax Service of Ukraine. (2021). Information on businesses that have a tax debt. Retrieved from [Google Scholar] Statute of SOE «EHealth» (new edition) approved by the Order of the Ministry of Health of Ukraine № 774 of April $20,2021$. Retrieved from [Link]

Tippmann, N. (2020). TOP 100 medical device startups with most money raised in 2020. Retrieved from [Link]

Unnithan, C., Houghton, A., Anema, A., \& Lemieux, V. (2019). Blockchain in Global Health: An Appraisal of Current and Future Applications. In Essentials of Blockchain Technology (pp. 189-204). Chapman and Hall/CRC. [Google Scholar]

WHO Global Observatory for eHealth. (2016). Atlas of eHealth country profiles: the use of eHealth in support of universal health coverage: based on the findings of the third global survey on eHealth 2015. World Health Organization. Retrieved from [Link] World Health Organization. (2016). Global diffusion of eHealth: making universal health coverage achievable: report of the third global survey on eHealth. Retrieved from [Link]

World Health Organization. (2018) Seventy-first World Health Assembly. Agenda item 12.4. Digital health. WHA 71.7. May 26, 2018. Retrieved from [Link]

YouControl. (2021). State enterprise Electronic Health. Retrieved from [Link]

Zhang, S., Liao, R., Alpert, J. S., Kong, J., Spetzger, U., Milia, P., ... \& Wortley, D. J. (2018). Digital medicine: Emergence, definition, scope, and future. Digital Medicine, 4(1), 1. [Google Scholar] 
Наталія Котенко, к.е.н., доцент, Сумський державний університет, Україна

Вікторія Бенхардт, підприємець, Німеччина

Фінансування проектів 3 цифрової медицини: виклики і можливості

Стаття узагальнює актуальні тенденції щодо фінансового забезпечення розвитку цифрової медицини в Україні 3 урахуванням вимог та рекомендацій міжнародних інституцій Основною метою проведеного дослідження є ідентифікація проблем та викликів, публічного фінансування в Україні та пошук ефективних шляхів їх вирішення з урахуванням світового досвіду. Систематизація літературних джерел та підходів до розв'язання проблеми фінансування проектів цифрової медицини засвідчила, що в більшості досліджень як вітчизняних, так і іноземних авторів представлені результати пошуку ефективних механізмів фінансування охорони здоров'я або технічні аспекти розвитку цифррової медицини та ї̈ складових. Однак, аналіз, проведений ВОО3, засвідчив, що для більшості країн світу, відсутність або недостатній рівень сталого фінансування $є$ непереборною перешкодою при впровадженні проектів цифррової медицини. Таким чином, це підтверджує актуальність розв'язання даної наукової проблеми. Методичним інструментарієм проведеного дослідження стали методи систематизації, структурного та порівняльного аналізу, логічного узагальнення. Практичну реалізацію дослідження здійснено за допомогою інструментарію програмного забезпечення Excel 2016. Початком дослідження було обрано 2016 рік, що є початком цифрової трансформації сфрери охорони здоров'я в Україні. Дослідження проблем фінансового забезпечення проектів цифрової медицини та ідентифікацію можливих шляхів їх вирішення здійснено в наступній логічній послідовності: проведено оцінку ефективності істабільності бюджетного фінансування проекту електронних записів щодо здоров'я в Україні в рамках ініціативи eHealth; проаналізовано сучасний стан фінансування Телемедицини і Мобільної медицини; на основі світового досвіду запропоновані потенційні напрямки розв'язання проблеми браку фінансування; проведено дослідження інноваційних проектів цифрової медицини, що реалізуються стартапами; виявлено залежність між обсягами венчурного фінансування і зрілістю та кількістю працівників компаній. За результатми дослідження запропоновано застосовувати технологї̈ Al, Big Data, блокчейн технологій, інтернет речей для налагодження співпраці між приватним, публічним секторами, науковими колами неурядовими організаціями.

Ключові слова: великі дані, відшкодування бюджету, державна політика, державно-приватне партнерство, електронне здоров'я, електронні медичні записи, охорона здоров'я, телемедицина, фінансування, штучний інтелект. 